\title{
PENGARUH MODEL PEMBELAJARAN KOOPERATIF TIPE MAKE A MATCH TERHADAP KEPERCAYAAN DIRI KELOMPOK B GUGUS I
}

\author{
Pt Aditya Antara ${ }^{1}$, Pt Rahayu Ujianti ${ }^{2}$, Dewi Ayu Surya Jayanti ${ }^{3}$ \\ 1,2,3 Jurusan Pendidikan Guru Sekolah Dasar, FIP \\ Universitas Pendidikan Ganesha \\ Singaraja, Indonesia \\ e-mail: putuadityaantara@undiksha.ac.id ${ }^{1}$, puturahayuujianti@undiksha.ac.id², \\ suryabuleleng7@gmail.com
}

\begin{abstract}
Abstrak
Penelitian ini bertujuan untuk mengetahui perbedaan yang signifikan pada anak kelompok B yang diberikan model pembelajaran kooperatif tipe make a match terhadap kepercayaan diri anak di TK Gugus I Kecamatan Buleleng. Jenis penelitian ini merupakan penelitian eskperimen semu (quasi experiment), dengan desain penelitian pre-posttest control group design. Populasi dalam penelitian ini adalah seluruh anak kelompok B pada gugus I Kecamatan Buleleng yang berjumlah 400 anak. Sampel ditentukan dengan teknik cluster random sampling. Sampel dalam penelitian ini berjumlah 36 anak. Data hasil kepercayaan diri dikumpulkan dengan teknik observasi yang dianalisis dengan menggunakan teknik analisis statistik deskriptif dan statistik inferensial dengan uji-t. Berdasarkan hasil analisis diperoleh $t_{\text {hitung }}=17,31$ sedangkan pada taraf signifikansi $5 \%$ dengan $\mathrm{dk}=34$ diperoleh $\mathrm{t}_{\text {tabe }} \mathrm{l}=1,690$ sehingga $\mathrm{t}_{\text {hitung }}=17,31>$ $t_{\text {tabel }}=1,690$. Berdasarkan kriteria pengujian, maka $H_{0}$ ditolak, ini berarti $\mathrm{H}_{1}$ diterima yang menyatakan terdapat perbedaan yang signifikan pada anak kelompok B yang diberikan model pembelajaran kooperatif tipe make a match terhadap kepercayaan diri anak di TK Gugus I Kecamatan Buleleng tahun pelajaran 2018/2019. Berdasarkan hasil penelitian dapat disimpulkan bahwa terdapat perbedaan yang signifikan pada anak kelompok B yang diberikan model pembelajaran kooperatif tipe make a match terhadap kepercayaan diri anak di TK Gugus I Kecamatan Buleleng.
\end{abstract}

Kata-kata kunci : Anak Usia Dini, Kepercayaan Diri, Model Make A Match

\begin{abstract}
This study aims to determine the significant differences in children in group B who were given a cooperative learning model type make a match to the confidence of children in Kindergarten Cluster I District of Buleleng. This type of research is a quasi experiment, with a pre-posttest control group design research design. The population in this study were all children in group B in cluster I of Buleleng Subdistrict, amounting to 400 children. The sample is determined by cluster random sampling technique. The sample in this study amounted to 36 children. Data on self-confidence results were collected by observation techniques which were analyzed using descriptive statistical analysis techniques and inferential statistics with t-test. Based on the results of the analysis obtained thitung $=17.31$ while at the significance level of $5 \%$ with $\mathrm{dk}=34$ obtained $\mathrm{t}$ table $=1.690$ so that $\mathrm{t}$ count $=17.31>\mathrm{t}$ table $=1.690$. Based on the testing criteria, then $\mathrm{Ho}$ is rejected, this means that $\mathrm{H} 1$ is accepted which states that there is a significant difference in children in group $\mathrm{B}$ given the cooperative learning model type make a match to children's self-confidence in TK Gugus I Sub-District Buleleng academic year 2018/2019.. Based on the results of the study it can be concluded that there is a significant difference in the group B children given the type of cooperative learning model make a match to the confidence of children in Kindergarten Cluster I District of Buleleng.
\end{abstract}

Keywords: Young Children, Self Confidence, Make A Match Model 


\section{Pendahuluan}

Anak usia dini adalah sosok individu yang sedang menjalani suatu proses perkembangan dengan pesat dan sangat fundamental bagi kehidupan selanjutnya. Pada usia ini anak paling peka dan memiliki rasa ingin tahu yang sangat besar. Ini dapat terlihat dari anak yang sering bertanya tentang apa yang mereka lihat dan mereka dengar, mereka juga lebih senang bermain dan melakukan sesuatu yang dianggap menarik. "la memiliki dunia dan karakteristik sendiri yang berbeda dari orang dewasa" menurut (Wahyudin dan Agustin, 2012:7). Hakekatnya setiap anak memiliki karakteristik dan keunikan yang berbeda-beda, dibalik keunikan itu tersimpan berbagai potensi yang perlu dikembangkan dan diarahkan sesuai pada jalurnya. Pengembangan berbagai potensi tersebut dilaksanakan dengan mengacu pada lingkup perkembangan anak usia dini yang tercantum dalam Permendikbud Nomor 146 Tahun 2014, yaitu: (1) pengembangan nilai-nilai agama dan moral, (2) pengembangan sosialemosional, (3) pengembangan bahasa, (4) pengembangan kognitif, (5) pengembangan fisik (motorik), dan (6) seni.

Selain mengacu pada lingkup perkembangan di atas, pembelajaran anak usia dini juga mengembangkan berbagai potensi yang dimiliki oleh anak. Sejalan dengan yang dikatakan Antara, 2015 "Pendidikan anak usia dini lebih mengutamakan proses pembelajaran yang terintegrasi karena anak memiliki berbagai potensi yang harus dikembangkan secara maksimal untuk berbagai kemampuan dalam memecahkan masalah kehidupannya di masa depan". Stimulasi yang diberikan harus mampu mengembangkan semua aspek perkembangan anak. Aspek perkembangan yang menekankan pada kemampuan anak dalam mengelola emosi dan bersosialisasi yaitu aspek perkembangan sosial-emosional. Perkembangan sosial dan emosional merupakan dua aspek yang berlainan, namun pada dasarnya saling mempengaruhi. Susanto (2011:134) "perilaku sosial dan emosional yang diharapkan dari anak usia dini adalah perilaku-perilaku yang baik, seperti kedisiplinan, kemandirian, tanggung jawab, percaya diri, jujur, adil, setia kawan, sifat kasih sayang terhadap sesama, dan memiliki toleransi yang tinggi". Perilaku sosial-emosional yang memiliki peranan penting dalam kehidupan anak yaitu kepercayaan diri. "Kepercayaan diri sangat dibutuhkan dalam kehidupan anak sebagai bekal dalam mengatasi setiap tantangan serta problematika hidupnya nanti" (Rahayu, 2013:58). Kepercayaan diri harus dimiliki setiap anak untuk menjalani kehidupannya yang akan berpengaruh terhadap perkembangan mental dan karakter mereka. Mental dan karakter yang kuat menjadi modal penting bagi masa depannya, sehingga dapat membantu dan memudahkan anak dalam mengatasi setiap masalah dan tantangan yang dihadapinya. Oleh karena itu, setiap pendidik perlu menanamkan kepercayaan diri kepada anak sejak dini. Tanpa dibekali rasa kepercayaan diri yang kuat, anak akan tumbuh menjadi pribadi yang lemah, manja dan pemalu. Kepercayaan diri dapat membantu anak untuk lebih mandiri.

Menurut (Affiatin dan Mulyani, 1998:66), "aspek kepribadian sangat penting untuk meningkatkan rasa percaya diri serta dalam mengaktualisasikan segala potensi yang dimiliki anak". Tanpa ada rasa percaya diri maka banyak masalah atau hambatan yang akan timbul pada anak. Rasa percaya diri pada anak sangatlah penting ketika anak tersebut akan mencoba bergaul dengan teman, atau memulai proses sosialisasi dengan lingkungan. Percaya diri juga dibutuhkan oleh anak-anak ketika mereka tampil di depan umum, ketika melakukan suatu kegiatan.

Menurut Budiono, dalam Hartuti (200:21), "orang yang memiliki rasa percaya diri memiliki keyakinan bahwa dirinya mampu melakukan tugas-tugas yang harus dikerjakan dan menyelesaikan dengan cara yang kreatif dan sikap positif terhadap kemampuan yang ada pada dirinya". Apabila kita memberi stimulasi yang baik, secara menyeluruh, kecerdasan anak akan berkembang secara optimal. Anak pandai dalam hal akademik, tetapi dari sisi kecerdasan sosial emosional anak juga berkembang, anak berani untuk melakukan sesuatu, melaksanakan tugas dan merasa percaya diri.

Kepercayaan diri tidak identik dengan kesombongan diri, justru orang yang sombong adalah orang yang rendah diri dan menutupi kekurangannya. Beri anak didik pujian dan penghargaan jika mampu menyelesaikan tugas dengan baik. Jika tidak, guru memberikan 
semangat pada peserta didik untuk mengerjakan tugasnya kembali. Konsep diri anak-anak berkembang secara perlahan dan akan terus berkembang berdasarkan realitas yang dihadapi anak dalam menjalankan proses pembelajarannya. "Orang tua, guru, teman sebaya adalah orang-orang yang sangat penting dalam dunia sosial anak dan hubungan mereka dengan anak dapat memperkuat atau melemahkan pembelajaran anak" (Santrock, 2017:486). Membangun kepercayaan diri anak serta menghargai dan mengoptimalkan potensi, guru perlu membangun kepercayaan diri peserta didik, menghargai potensi dan berupaya mengoptimalkannya. Kepercayaan diri menjadi hal yang sangat penting dan menjadi dasar peserta didik untuk memahami dan mempercayai kenyataan dirinya, kelemahan, kekuatan, dan potensi yang dimiliki serta anak akan percaya bahwa ia mampu mengembangkan potensinya sesuai dengan kemampuannya.

Berdasarkan hasil observasi yang dilakukan pada TK Gugus 1 Kelompok B Kecamatan Buleleng, 11 orang anak yang belum mempunyai rasa percaya diri tinggi dalam satu kelas yang jumlahnya 19 orang, masih banyak anak yang rasa percaya diri mereka belum tumbuh. Hal tersebut ditunjukkan dengan belum adanya rasa percaya diri anak, untuk melakukan kegiatan yang diberikan guru, mereka selalu berkata "Bu, aku tidak bisa!" ketika akan mengerjakan tugas. Masih ada sebagian anak yang belum bisa bergaul dengan temantemannya, mereka lebih senang menjadi penonton ketika teman-teman mereka sedang bermain. Selain itu, ketika anak-anak melakukan tugas kelompok, mereka masih sering belum bisa menerima kritik, saran, atau pendapat teman lain, ketika anak diberi masukan dari teman lain, mereka belum bisa menerima dan akhirnya menangis.

Berdasarkan pengamatan anak-anak juga cenderung pasif, bisa dilihat ketika ibu guru meminta anak-anak untuk maju melakukan suatu kegiatan, tidak semuanya bersedia maju untuk melakukan kegiatan tersebut. Mungkin dari satu kelas yang berjumlah 19 anak yang aktif hanya 8 anak, bahkan mereka selalu mengangkat tangan dan meminta kepada bu guru untuk melakukan terlebih dulu sedangkan anak lainnya memilih untuk diam dan tidak maju, mereka belum mempunyai rasa percaya diri yang tinggi, sehingga tidak berani untuk maju dan tampil di depan. Selama ini guru memberikan kegiatan kepada anak-anak sesuai dengan tingkat pencapaian perkembangan dan kurikulum saja, seperti menggunakan lembar kerja, selain itu guru selalu memberi motivasi kepada anak-anak semua dan memberikan kegiatan yang bisa menumbuhkan rasa percaya diri pada anak, misal dengan bercerita, bernyanyi di depan. Kegiatan yang diberikan guru dianggap belum optimal menumbuhkan rasa percaya diri anak, oleh karena itu perlu dilakukan penelitian.

Menanamkan kepercayaan diri pada anak di Taman Kanak-kanak hendaknya dilaksanakan melalui kegiatan atau metode yang bervariasi, agar pembelajaran dapat menarik bagi anak dan dapat menumbuhkan kepercayaan diri. Seiring dengan perkembangan zaman dari waktu ke waktu model pembelajaran semakin banyak dan bermacam-macam. Hal tersebut dipaparkan kembali oleh Ngalimun (2012: 27) bahwa "model pembelajaran merupakan suatu perencanaan atau suatu pola yang digunakan dalam merencanakan pembelajaran di kelas". Atas dasar pendapat di atas model pembelajaran dapat dipahami sebagai model pembelajaran yang memiliki rancangan yang lebih diprogram melalui alat peraga untuk menyampaikan pesan dan mencapai tujuan belajar. Hamiyah dan Jauhar (2014:57) mengatakan bahwa "model pembelajaran merupakan cara/teknik penyajian yang digunakan guru dalam proses pembelajaran agar tercapainya tujuan pembelajaran". Pembelajaran sering kali membaik bila anak diberikan kesempatan untuk berinteraksi, bekerjasama dengan orang lain dalam menangani tugas-tugas instruksional. Dalam situasi ini, anak-anak punya kesempatan untuk menciptakan perspektif dan berpikir reflektif sehingga memperkuat rasa percaya diri dan perkembangan mereka.

Hubungan Interpersonal yang berkualitas dapat menghasilkan rasa percaya dan perhatian sehingga meningkatkan rasa memiliki, penghargaan diri, penerimaan diri, dan menghasilkan iklim pembelajaran yang positif. Salah satu metode pembelajaran yang meningkatkan kepercayaan diri anak yakni model pembelajaran kooperatif, menurut Slavin dalam Isjoni (Weni, dkk., 2016) mengatakan bahwa "pembelajaran kooperatif adalah suatu model pembelajaran dimana sistem belajar dan bekerja dalam kelompok kecil berjumlah 4-6 
orang secara kolaboratif sehingga dapat merangsang peserta didik lebih bergairah dalam belajar". Hal tersebut juga di sampaikan Sanjaya (dalam Kasmad dan Pratomo, 2012: 33) mengatakan bahwa "pembelajaran kooperatif merupakan model pembelajaran yang menggunakan sistem pengelompokkan atau tim kecil, yaitu antara empat sampai enam orang yang mempunyai latar belakang kemampuan akademik, jenis kelamin, ras, atau suku yang berbeda (heterogen)".

Make A Match merupakan salah satu pembelajaran kooperatif yang dikembangkan pertama kali pada tahun 1994 oleh Lorna Curran, salah satu keunggulan teknik ini adalah siswa mencari pasangan sambil belajar mengenai konsep atau topik dalam suasana yang menyenangkan. (Ngalimun, 2014:176) mengatakan bahwa,

guru menyiapkan kartu yang berisi persoalan permasalahan dan kartu yang berisi jawabannya, setiap siswa mencari dan mendapatkan sebuah kartu soal dan berusaha menjawabnya, setiap siswa mencari kartu yang cocok dengan persoalannya siswa yang benar mendapat nilai-reward, kartu di kumpulkan lagi dan dikocok, untuk babak berikutnya pembelajaran seperti babak pertama, penyimpulan dan evaluasi, refleksi. Langkah-langkah pembelajaran make a match merupakan bentuk pembelajaran dalam kelompok.

(Mertadi, 2013:4) mengungkapkan, kelebihan menggunakan model pembelajaran make a match sebagai berikut: 1) Siswa terlibat langsung dalam menjawab soal yang di sampaikan kepadanya melalui kartu 2) Meningkatkan kreativitas belajar para siswa 3) Menghindari kejenuhan siswa dalam mengikuti kegiatan belajar dan mengajar 4) Pembelajaran lebih menyenangkan karena melibatkan media pembelajaran yang dibuat oleh guru.

Dalam model pembelajaran kooperatif ini peserta dituntut untuk berani berinteraksi dengan teman sekelas yang bertujuan untuk mendapatkan jawaban atau kartu dari soal tersebut, dan mempercayakan kemampuannya pada saat pembelajaran tersebut.

Berdasarkan paparan diatas maka peneliti bermaksud menguji perbedaan yang signifikan pada anak kelompok $\mathrm{B}$ yang diberikan model pembelajaran kooperatif tipe make a match terhadap kepercayaan diri anak di TK Gugus I Kecamatan Buleleng tahun pelajaran 2018/2019".

\section{Metode}

Penelitian ini menggunakan penelitian eksperimen semu (quasi experiment), dengan rancangan yang dilakukan dalam penelitian adalah Non-equivalen control group design. Dengan desain Pre-Posttest control group design.

Penelitian ini dilakukan pada kelompok B Taman Kanak-Kanak Gugus I Kecamatan Buleleng. Penelitian kelas eksperimen dilaksanakan pada kelompok B TK Kuncup Harapan yang bertempat di Jalan Pulau Ceningan No.4 Yeh Taluh Penarukan Singaraja dan penelitian kelas kontrol dilaksanakan pada kelompok B di TK Satya Kumara yang beralamat di Desa Penglatan. Penelitian ini dilaksanakan pada rentang waktu semester II (genap) tahun 2018/2019.

(Agung, 2016:69) menyatakan bahwa "populasi adalah keseluruhan objek dalam suatu penelitian". (Koyan, 2012:30) menyatakan bahwa populasi adalah himpunan dari unsur-unsur sejenis. Populasi dalam penelitian ini adalah para peserta didik di TK Gugus I Kecamatan Buleleng Kelompok B Tahun Pelajaran 2018/2019. Jumlah kelompok B Keseluruhan di TK Gugus I adalah 16 kelompok. Populasi dalam penelitian ini adalah seluruh anak kelompok B Gugus I Kecamatan Buleleng. (Agung, 2016:69),

Sampel ialah sebagian dari populasi yang diambil, yang dianggap mewakili seluruh populasi dan diambil dengan menggunakan teknik tertentu. Sedangkan (Trianto, 2011:231) mengatakan "bahwa sampel adalah sebagian dari populasi yang memiliki ciri-ciri atau sifat-sifat yang sama dan/ serupa dengan populasinya". Sesuai dengan rumusan tersebut, sampel harus memiliki ciri-ciri atau sifat-sifat yang menggambarkan secara tepat sifat-sifat dari populasinya. Teknik yang digunakan mengambil sampel dari populasi disebut "Teknik Sampling" ini menggunakan teknik cluster random sampling.

Agung (2014:74) menyatakan teknik ini biasa juga diterjemahkan dengan cara pengambilan sampel berdasarkan gugus. Jadi pada cluster random sampling ini anggota 
sampel bukan individu-individu dari populasi, melainkan kelompok-kelompok individu. Teknik cluster random sampling dilakukan untuk menentukan kelas yang dijadikan sampel saja, bukan untuk menentukan siswa-siswa yang termasuk ke dalam kelas eksperimen dan kelas kontrol. Jadi dalam penelitian ini sampel kelompok eksperimen yakni TK Kuncup Harapan dan sampel kelompok kontrol yakni TK Satya Kumara.

Variabel adalah objek penelitian yang menjadi titik fokus dalam sebuah penelitian (Agung, 2014). Variabel bebas adalah "satu atau lebih dari variabel-variabel yang sengaja dipelajari pengaruhnya terhadap variabel tergantung" (Agung, 2014:42). Variabel bebas dalam penelitian ini adalah model pembelajaran kooperatif tipe make a match, Variabel terikat/tergantung adalah "variabel yang keberadaanya atau munculnya bergantung pada variabel bebas" (Agung, 2014:42). Variabel terikat/tergantung dalam penelitian ini adalah kepercayaan diri.

Pengumpulan data dalam penelitian ini menggunakan teknik observasi, teknik observasi digunakan untuk menilai kegiatan atau pengamatan terhadap perlakuan. Untuk mengukur kepercayaan diri anak dengan teknik observasi dengan melibatkan beberapa aspek kepercayaan diri: (1) Keyakinan pada kemampuan diri (2) Bertanggungjawab (3) Kemampuan bergaul (4) Menerima kritik. Instrumen penelitian untuk mengukur kepercayaan diri anak digunakan check list. Pengisian check list kepercayaan diri anak melingkari pada kolom alternative yang paling sesuai dengan keadaan anak. Ini dilakukan oleh peneliti mengingat anak usia dini belum mampu untuk membaca. Penyusunan instrumen penelitian berdasarkan teori-teori yang tahap perkembangan sosial anak usia 5 sampai 6 tahun yang telah dipaparkan sebelumnya.

Pengujian validitas butir kepercayaan diri dalam penelitian ini dilakukan dengan mengkorelasikan skor setiap butir item yanga diuji dengan $r_{\text {tabel }}$ melalui uji korelasi product moment dengan memanfaatkan Microsoft Excel 2013 For Windows. Butir item yang diuji adalah sebanyak 11 butir, subjek atau responden yang dilibatkan untuk pengujian adalah anak kelompok B TK Gugus IV Kecamatan Buleleng berjumlah 20 anak. Analisis semua butir memenuhi kriteria sebagai butir yang valid dengan Nilai $r_{x y}>0,444$.

Pengujian reliabilitas instrumen kepercayaan diri dalam penelitian ini dilakukan dengan Alpha Cronbach melalui Microsoft Excel 2013 For Windows menunjukkan nilai $r_{11}$ sebesar 0,78 atau berada pada kriteria reliabilitas instrumen tinggi. Sehingga dengan demikian instrumen kepercayaan diri layak untuk digunakan sebagai alat untuk pengumpulan data dalam penelitian ini.

Setelah data dalam penelitian ini terkumpul, maka selanjutnya dilakukan analisis data. Dalam menganalisis data digunakan metode analisis statistik deskriptif. Metode analisis deskriptif ialah suatu cara pengolahan data yang dilakukan dengan jalan menerapkan rumusrumus statistik deskriptif seperti, skor rata-rata (mean), median (Me), modus (Mo), untuk menggambarkan suatu objek/variabel tertentu sehingga diperoleh kesimpulan umum.

Analisis deskriptif digunakan untuk mengetahui tinggi rendahnya kualitas dari dua variabel yaitu model pembelajaran kooperatif tipe make a match dengan kepercayaan diri. Pada penelitian ini untuk ketepatan hasil deskripsi data, akan dikonversikan dengan kriteria yang dihitung menggunakan mean, median, modus. Sebelumnya, terlebih dahulu dicari rentangan skor untuk menentukkan jumlah skor interval dan menetukkan panjang kelas.

Uji normalitas sebaran data dimaksudkan untuk memperlihatkan bahwa data sampel benar-benar berasal dari populasi yang berdistribusi normal sehingga uji hipotesis dapat dilakukan. Pengujian normalitas dilakukan untuk mengetahui normal tidaknya distribusi data. Hal ini penting diketahui berkaitan ketepatan uji statistik yang akan digunakan. Uji normalitas sebaran data untuk skor kepercayaan diri menggunakan perhitungan manual. Kriteria pengujian apabila $d_{\text {hitung }}<d_{\text {tabel }}=0,309$ maka distribusi data diasumsikan normal dan apabila sebaliknya dhitung >dtabel=0,309 maka data diasumsikan tidak berdistribusi normal.

Uji homogenitas varians antar kelompok dilakukan dengan mengetahui setiap varians antara setiap kelompok mempunyai varians yang sama antara anggota kelompok tersebut. Uji homogenitas diperlukan terutama pada pengujian beda rata-rata yang independen. Uji homogenitas ini dilakukan untuk mencari tingkat kehomogenan secara dua pihak yang diambil dari kelompok-kelompok terpisah dari satu populasi yaitu kelompok eksperimen dan kontrol. 
Salah satu prasyarat yang harus dipenuhi menggunkan uji-t adalah bahwa varians dalam kelompok harus homogen.

Uji hipotesis yang dilakukan dalam penelitian ini menggunakan analisis uji-t karena penelitian ini merupakan penelitian dengan membandingkan satu variabel bebas dan satu variabel terikat yang datanya bersifat interval. Hipotesis yang diambil yaitu terdapat pengaruh yang signifikan terhadap kepercayaan diri pada anak antara yang kelompok yang diberikan model pembelajaran kooperatif tipe make a match dengan kelompok yang diberikan bukan model pembelajaran kooperatif tipe make a match pada anak kelompok B Taman Kanak-kanak Gugus I Kecamatan Buleleng.

\section{Hasil dan Pembahasan}

Hipotesis penelitian yang diuji dalam penelitian ini adalah hipotesis nol (Ho) yang berbunyi tidak terdapat perbedaan yang signifikan pada anak kelompok B yang diberikan model pembelajaran kooperatif tipe make a match terhadap kepercayaan diri anak di TK Gugus I Kecamatan Buleleng

Sedangkan hipotesis satu $\left(\mathrm{H}_{1}\right)$ yang berbunyi terdapat perbedaan yang signifikan pada anak kelompok $\mathrm{B}$ yang diberikan model pembelajaran kooperatif tipe make a match terhadap kepercayaan diri anak di TK Gugus I Kecamatan Buleleng.

Hasil posttest terhadap 18 orang anak kelompok eksperimen menunjukkan bahwa skor tertinggi 41 dan skor terendah 33 dengan angka rata-rata 36,83. Berdasarkan perhitungan dan grafik polygon diatas terlihat dari hasil perhitungan tersebut didapatkan nilai $\mathrm{Mo}>\mathrm{Me}>\mathrm{M}$ atau $38>37>36,83$. Maka data tersebut termasuk pada distribusi juling negatif (sebagian besar skor hasil kepercayaan diri anak cenderung tinggi). Grafik posttest kelompok eksperimen dapat dilihat pada Gambar 1.

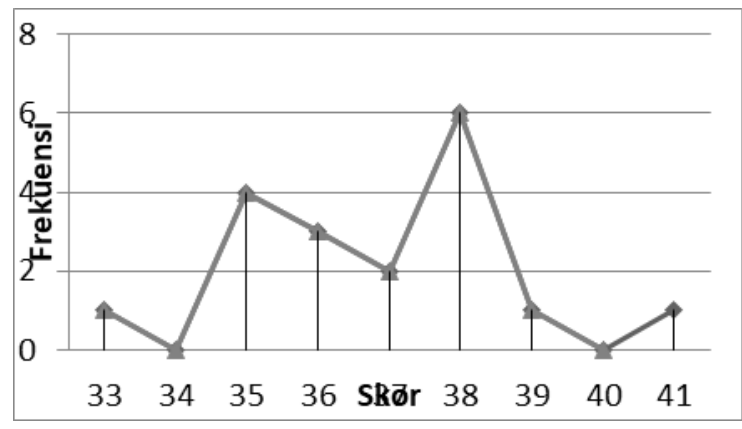

Gambar 1. Grafik Posttest Kelompok Eksperimen

Nilai rata-rata kelompok eksperimen melalui model pembelajaran kooperatif tipe make a match adalah 36,83 . Nilai rata-rata jika dikonversikan dalam tabel skala lima rata-rata berada pada 35,75-<44 yang berarti sangat tinggi berarti kepercayaan diri anak berada pada kategori sangat tinggi. Tabel konversi skala lima dapat dilihat pada Tabel.1.

Tabel 1. Skala Lima Kepercayaan Diri Anak

\begin{tabular}{clc}
\hline No & \multicolumn{1}{c}{ Rentangan Skor } & Klasifikasi/Predikat \\
\hline 1 & $35,75-<44$ & Sangat baik/Sangat tinggi \\
2 & $30,25-<35,75$ & Baik/Tinggi \\
3 & $24,75-<30,25$ & Cukup/Sedang \\
4 & $19,25-<24,75$ & Tidak Baik/ Rendah \\
5 & $11-<19,25$ & Sangat tidak baik/Sangat rendah \\
\hline
\end{tabular}


Hasil posttest terhadap 18 orang anak kelompok kontrol menunjukkan bahwa skor tertinggi 31 dan skor terendah 24 dengan angka rata-rata 26,44. Berdasarkan perhitungan dan grafik polygon diatas terlihat dari hasil perhitungan tersebut didapatkan nilai $\mathrm{Mo}<\mathrm{Me}<\mathrm{M}$ atau $25>25,5>26,44$. Maka data tersebut termasuk pada distribusi juling positif (sebagian besar skor hasil kepercayaan diri anak cenderung rendah). Grafik posttest kelompok kontrol dapat dilihat pada Gambar 2.

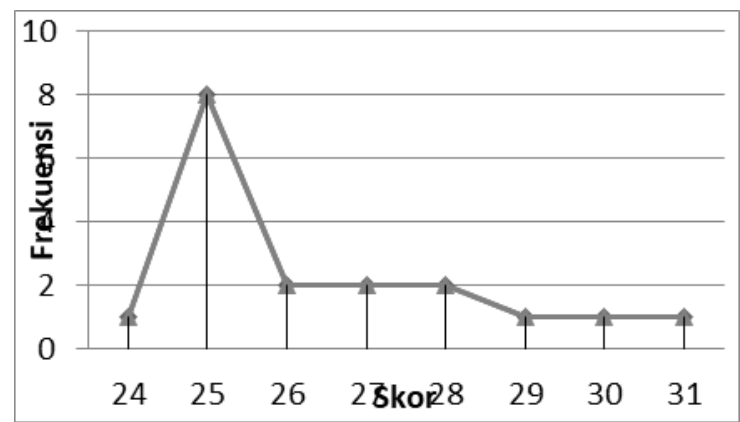

Gambar 2. Grafik Posttest Kelompok Kontrol

Nilai rata-rata kelompok kontrol melalui metode pembelajaran konvensional adalah 26,44. Nilai rata-rata jika dikonversikan dalam tabel skala lima rata-rata berada pada $19,25-<24,75$ yang berarti kepercayaan diri anak berada pada kategori tidak baik. Tabel konversi skala lima dapat dilihat pada Tabel 2.

Tabel 2. Skala Lima Kepercayaan Diri Anak

\begin{tabular}{clc}
\hline No & \multicolumn{1}{c}{ Rentangan Skor } & Klasifikasi/Predikat \\
\hline 1 & $35,75-<44$ & Sangat baik/Sangat tinggi \\
2 & $30,25-<35,75$ & Baik/Tinggi \\
3 & $24,75-<30,25$ & Cukup/Sedang \\
4 & $19,25-<24,75$ & Tidak Baik/ Rendah \\
5 & $11-<19,25$ & Sangat tidak baik/Sangat rendah \\
\hline
\end{tabular}

Berdasarkan hasil uji normalitas diperoleh nilai $d_{\text {hitung }}$ sebesar $0,188<$ dari $d_{\text {tabel }}$ dengan nilai 0,309 . Dengan demikian signifikan $d_{\text {hitung }}<d_{\text {tabel }}(0,188<0,309)$, maka Ho diterima dan Ha ditolak. Hal ini berarti sebaran data nilai posttest pada kelompok eksperimen berdistribusi normal. Begitu juga dengan kelompok kontrol nilai $d_{\text {hitung }}$ sebesar $0,144<$ dari $d_{\text {tabel }}$ dengan nilai 0,309 . Dengan demikian $d_{\text {hitung }}<d_{\text {tabel }}(0,144<0,309)$ maka Ho diterima dan Ha ditolak. Hal ini berarti sebaran data nilai posttest pada kelompok kontrol berdistribusi normal.

Berdasarkan perhitungan uji homogenitas dengan Uji Fisher (Uji F) diperoleh $f_{\text {hitung }}=1,09$ dan nilai $\mathrm{f}_{\text {tabel }}=4,13$ pada taraf signifikansi $5 \%$ dengan df $1=2-1=1$, dan df $2=36-2=34$. Karena $f_{\text {hitung }}=1,09<f_{\text {tabel }}=4,13$, maka Ho diterima. Sehingga data kedua kelompok memiliki varians yang homogen.

Berdasarakan analisis data menggunakan uji-t diperoleh $t_{\text {hitung }}=17,31$ dan $t_{\text {tabel }}$ dengan $\mathrm{db}=18+18-2=34$ dengan taraf signifikansi $5 \%=1,690$ dengan demikian $t_{\text {hitung }}>t_{\text {tabel }}=$ 17,31>1,690, maka Ho ditolak dan $\mathrm{H}_{1}$ diterima. Maka dapat disimpulkan bahwa terdapat perbedaan yang signifikan pada anak kelompok B yang diberikan model pembelajaran kooperatif tipe make a match terhadap kepercayaan diri anak di TK Gugus I Kecamatan Buleleng.

Berdasarkan data dari hasil penelitian ini menunjukkan bahwa model pembelajaran kooperatif tipe make a match berpengaruh secara signifikan terhadap kepercayaan diri pada anak. Hal ini dikarenakan beberapa hal diantaranya dalam model pembelajaran kooperatif tipe 
make a match mengajak anak mencari pasangan sambil belajar mengenai suatu konsep atau topik dalam suasana yang menyenangkan. Model pembelajaran kooperatif tipe make a match memupuk kerjasama siswa dalam menjawab pertanyaan dengan mencocokkan kartu gambar yang ada di tangan siswa. Model pembelajaran kooperatif tipe make a match memunculkan antusias siswa dalam proses pembelajaran karena lebih menarik. Model pembelajaran kooperatif tipe make a match mengajak siswa berinteraksi dan bekerja sama dengan teman sebaya sebagai kelompok yang mana dapat meningkatkan kepercayaan diri anak ketika proses pembelajaran. Hal ini sesuai dengan pernyataan Lorna Curran (1994) "Pembelajaran kooperatif ialah pembelajaran yang menitikberatkan pada gotong royong dan kerja sama kelompok". Pembelajaran kooperatif menekankan pada pembelajaran dalam kelompok heterogen yang saling membantu satu sama lainnya, bekerja sama menyelesaikan masalah, dan menyatukan pendapat untuk memperoleh keberhasilan yang optimal baik secara kelompok maupun individual.

Hal ini menunjukkan model pembelajaran kooperatif tipe make a match berpengaruh secara signifikan terhadap kepercayaan diri pada anak. Hal ini juga didukung secara empiris melalui penelitian eksperimen yang telah dilakukan. Berdasarkan hasil temuan pada kedua kelompok yang pada awalnya memiliki kemampuan setara, setelah diberikan perlakuan pada kelompok eksperimen maka perolehan nilai kepercayaan diri pada anak mengalami perbedaan yang signifikan. Kepercayaan diri pada anak pada kelompok eksperimen lebih baik apabila dibandingkan dengan kepercayaan diri anak pada kelompok kontrol. Hal ini dapat dilihat juga pada rata-rata siswa kelompok eksperimen dan siswa kelompok kontrol. Perbedaan kepercayaan diri tersebut karena adanya model pembelajaran kooperatif tipe make a match yang diterapkan pada kelompok eksperimen.

\section{Simpulan dan Saran}

Berdasarkan hasil analisis data dan pembahasan, yang menggunakan uji-t diperoleh nilai $t_{\text {hitung }}$ adalah 17,31 sedangkan $t_{\text {tabel }}$ adalah 1,690. Dengan demikian $t_{\text {hitung }}$ lebih besar dari pada $t_{\text {tabel }}=17,31>1,690$ maka, Ho ditolak dan $\mathrm{H}_{1}$ diterima. Jadi dapat disimpulkan bahwa terdapat perbedaan yang signifikan pada anak kelompok $B$ yang diberikan model pembelajaran kooperatif tipe make a match terhadap kepercayaan diri anak. Dengan adanya perbedaan kepercayaan diri pada kelompok eksperimen dan kontrol, hal ini berarti terdapat perbedaan yang signifikan pada anak kelompok B yang diberikan model pembelajaran kooperatif tipe make a match terhadap kepercayaan diri anak di TK Gugus I Kecamatan Buleleng.

Saran yang dapat disampaikan berdasarkan penelitian yang telah dilakukan adalah sebagai berikut. Bagi Guru. Guru disarankan menggunakan model pembelajaran kooperatif tipe make a match dalam proses kegiatan pembelajaran untuk mengoptimalkan kepercayaan diri anak. Tidak hanya menggunakan metode konvensional yang dilakukan di kelas maupun di luar kelas untuk mengoptimalkan kepercayaan diri anak. Bagi Kepala Taman Kanak-kanak. Sekolah yang mengalami permasalahan kepercayaan diri pada anak didiknya untuk kepala sekolah agar mendorong guru-guru untuk memaksimalkan penerapan model pembelajaran make a match yang akan dierapkan di kelas. Bagi Peneliti Lain. Peneliti yang berminat untuk mengadakan penelitian lebih lanjut tentang pengaruh model pembelajaran make a match terhadap kepercayaan diri anak, maupun aspek perkembangan lainnya yang sesuai agar memperhatikan kendala-kendala yang dialami dalam penelitian sebagai pertimbangan untuk perbaikan dan penyempurnaan penelitian yang akan dilaksanakan.

\section{Daftar Pustaka}

Agung. A. A. G. 2014. Metodologi Penelitian Pendidikan. Singaraja: Aditya Media Publishing.

Agung. A. A. G. 2016. Statistika Dasar Untuk Pendidikan. Yogyakarta: CV Budi Utama 
Agung. A. A. G. 2017. Evaluasi Pendidikan. Singaraja: Undiksha.

Agung, A. A. G dan I Nyoman Jampel. 2018. Statistik Inferensial untuk Pendidikan (Disertai Aplikasi SPSS). Singaraja: Undiksha.

Antara, 2015."Pengembangan Bakat Seni Anak Pada Taman Kanak-Kanak". Tersedia pada http://journal.unj.ac.id/jurnal fip/index.php/visi/article/view/2/0 (diakses tanggal 27 Februari 2019).

Antara, 2018." Pengaruh Model Pembelajaran Snowball Throwing Terhadap Perilaku Prososial Anak Kelompok B Di Gugus II". Tersedia pada https://ejournal.undiksha.ac.id/index.php/JJPAUD/article/view/15315 (diakses tanggal 27 Februari 2019).

Candiasa. 2011. Pengujian Instrumen Penilaian Disertai Aplikasi ITEMAN dan BIGSTEPS. Singaraja: Undiksha Press.

Hidayat, Komaruddin dan Bashori.2016. Psikologi Sosial. Jakarta: Penerbit Erlangga.

Khodijah. Nyayu, 2014.Psikologi Pendidikan.Jakarta: Rajawali Pers.

Koyan, I Wayan. 2012. Statistik Pendidikan Teknik Analisis Data Kuantitatif. Bali.Undiksha.

Kurniasih dan Berlin, 2015. Ragam Model Pembelajaran Untuk Peningkatan Profesionalitas Guru.Jakarta: Kata Pena.

Pritandhari. Meyta, 2017. "Implementasi Model Pembelajaran Direct Instruction Untuk Meningkatkan Kemampuan Berpikir Kreatif Mahasiswa".Jurnal Promosi.Vol.5.No.1.2017.

Prawistri. 2013. “Upaya Meningkatkan Rasa Percaya Diri Anak Kelompok B Melalui Kegiatan Bermain Aktif Di TK Pembina Kecamatan Bantul". Tersedia pada http://journal.student.uny.ac.id/jurnal/artikel/5430/16/588 (diakses tanggal 27 Februari 2019.

Rahayu, Aprianti Yofita. 2013. Menumbuhkan Kepercayaan Diri Melalui Kegiatan Bercerita. Jakarta: PT Indeks.

Santrock. John W, 2017.Psikologi Pendidikan.Jakarta: Kencana.

Sharan. Sholomo, 2012. The Handbook of Cooperative Learning.Yogyakarta: Familia.

Siyani, 2016. Penerapan Permainan Tradisional Meong-meongan untuk meningkatkan Percaya Diri Anak. Skripsi (tidak diterbitkan). Jurusan Pendidikan Guru Pendidikan Anak Usia Dini. Universitas Pendidikan Ganesha.Singaraja.

Suciati, 2016. Pengaruh Kegiatan Finger Painting Berbasis Teori Lokomosi terhadap Keterampilan Motorik Halus Anak Kelompok B Pada Tahun Pelajaran 2015/2016 di TK Widya Kumarasthana Banyuning. Skripsi (tidak diterbitkan). Jurusan Pendidikan Guru Pendidikan Anak Usia Dini. Universitas Pendidikan Ganesha Singaraja.

Surna. I Nyoman dan Pandeirot, 2014.Psikologi Pendidikan 1.Jakarta: Penerbit Erlangga.

Susanto. Ahmad.2012.Perkembangan Anak Usia Dini.Jakarta.Kencana. 
Trianto. 2011. Pengantar Penelitian Pendidikan bagi Pengembangan Profesi Pendidikan dan Tenaga Kependidikan.Jakarta.Kencana.

Wahyudin dan Agustin, 2012. Penilaian Perkembangan Anak Usia Dini.Bandung: Refika Aditama.

Weni, Oksiana, dkk. 2016. "Penerapan Model Pembelajaran Kooperatif tipe Make a match terhadap aspek perkembangan kognitif dan sosial emosional pada anak usia dini TK Negeri Pembina". Tersedia pada http://jurnalstkipmelawi.ac.id/index.php/JPD /article/view/101 (diakses tanggal 27 Februari 2019) 